\title{
Perioperative and Early Postoperative Outcome of Proximal Femoral Nailing for Stable and Unstable Trochanteric Fractures
}

\author{
Nina Đorđević ${ }^{1,2}$, Miloš Stanojlović ${ }^{\text {, Saša Milenković }}{ }^{1,2}$, \\ Predrag Stojiljković ${ }^{1}$, Mirjana Kociće,3, Ivan Golubović ${ }^{1}$ \\ ${ }^{1}$ Clinic for Orthopedics and Traumatology, Clinical Center Niš, Niš, Serbia \\ ${ }^{2}$ University of Niš, Faculty of Medicine, Niš, Serbia \\ ${ }^{3}$ Clinic of Physical Medicine and Rehabilitation, Clinical Center Nišs, Niš, Serbia
}

\section{SUMMARY}

The aim of the study was to analyze perioperative parameters as well as early postoperative period of patients with trochanteric fractures nailing in relation to the fracture stability.

The prospective study included 46 patients with trochanteric fractures fixed with the third generation cephalomedullary nail. Two groups were formed - stable fractures (Group 1) and unstable fractures (Group 2). There were 20 patients in Group 1, and 26 in Group 2. All the patients underwent Bioimpianti "basic-nail" fracture fixation. Perioperative and early postoperative parameters were monitored and the groups were compared.

The average duration of surgery in both groups was not significantly different. The number of patients needing transfusion as well as the average transfusion volume was similar in both groups. Average Intensive care unit (ICU) stay and hospitalization were longer in Group 1, though not significantly. In both groups, $80 \%$ of patients started early rehabilitation according to the protocol.

Trochanteric fracture fixation with Bioimpianti "Basic-nail" is a minimally invasive, safe method, giving the similar perioperative and early postoperative outcome regardless of the fracture stability. It enables fast postoperative recovery and reduction of early postoperative complications.

Key words: trochanteric fracture, stability, cephalomedullary nail, operative outcome, early postoperative rehabilitation 


\section{INTRODUCTION}

Trochanteric (pertrochanteric/ intertrochanteric) fractures account for almost $40 \%$ of all proximal femoral fractures (1). They are a significant cause of increased mortality and morbidity in elderly patients. If not fixed operatively, this fracture leads to prolonged disability and numerous complications. In 1949, Evans described the first trochanteric fracture fixation technique using the elastic intramedullary nails (2). This technique was abandoned due to the several draw-backs. Nevertheless, the idea of the intramedullary fixation inspired further biomechanical tests and development of rigid nails fixation. The prototype of the cephalomedullary or short femoral nail (Gamma nail) for the first time, according to G. Taglang, was inserted in December 1986 (3). Since then, this method of proximal femoral fracture fixation has been continually developed and the third generation of the cephalomedullary nails has already been promoted. The technological features of this nail have significantly reduced the complications.

According to its characteristics, Bioimpianti "basic-nail" is the cephalomedullary nail of the third generation. It has the same characteristics as the other third generation nails but has the potential of additional lag screw compression as well. Standard $(190 \mathrm{~mm})$ and intermediate $(250 \mathrm{~mm})$ nails are used for trochanteric fractures fixation. The standard nail has the guided locking possibility, whereas for the intermediate nail the "free-hand" technique is needed.

The cephalomedullary trochanteric nailing technique has been improved alongside with the nail design. Nowadays, it is a safe, minimally invasive procedure, primarily indicated for the unstable trochanteric fractures fixation (3-6). This procedure has also shown excellent results in very old patients (7). Elderly patients with unstable trochanteric fractures demand stable fixation with the least invasive technique and prompt postoperative activation and mobilization.

The aim of the study was to monitor perioperative parameters and the early postoperative period of patients with trochanteric fractures nailing in relation to the fracture stability.

\section{MATERIAL AND METHODS}

The prospective study included 46 patients with trochanteric fractures, 22 male and 24 female, the average age being 74 years. The fracture stability was assessed according to Jensen-Michaelsen classification (8) (Figure 1). (Group 1 - stable fractures; Group 2unstable fractures) (Figure 2 ). There were 20 patients with the average age of 77 years in Group 1, and 26 with the average of age 71 years in Group 2.
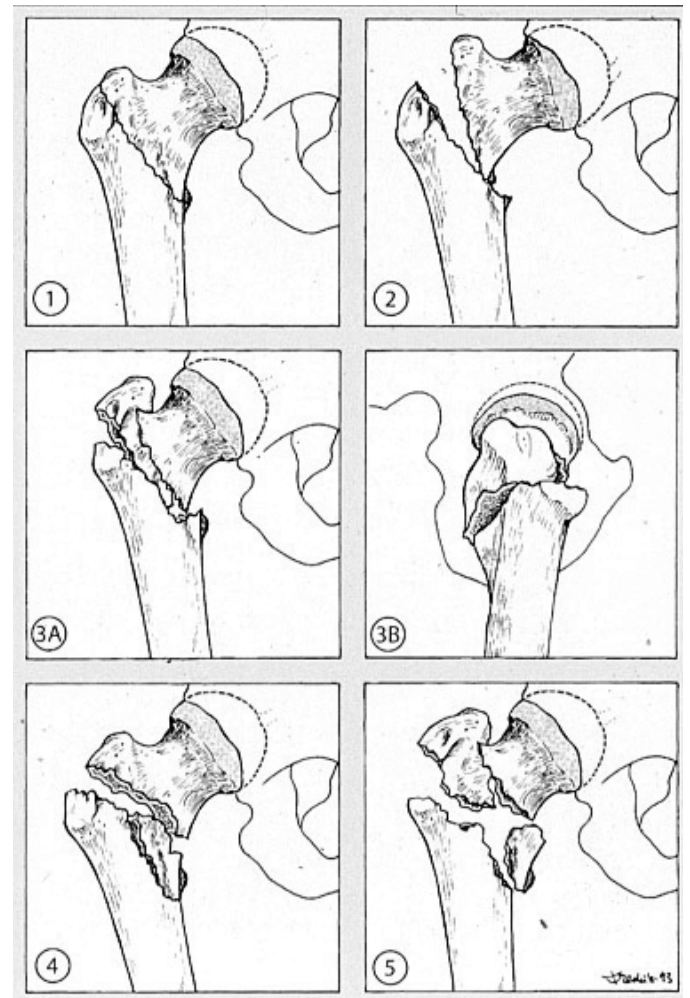

Figure 1: Jansen-Michaelsen classification of trochantric fractures. Types 1 and 2 are stable. Types $3 a, 3 b, 4$ and 5 are unstable.

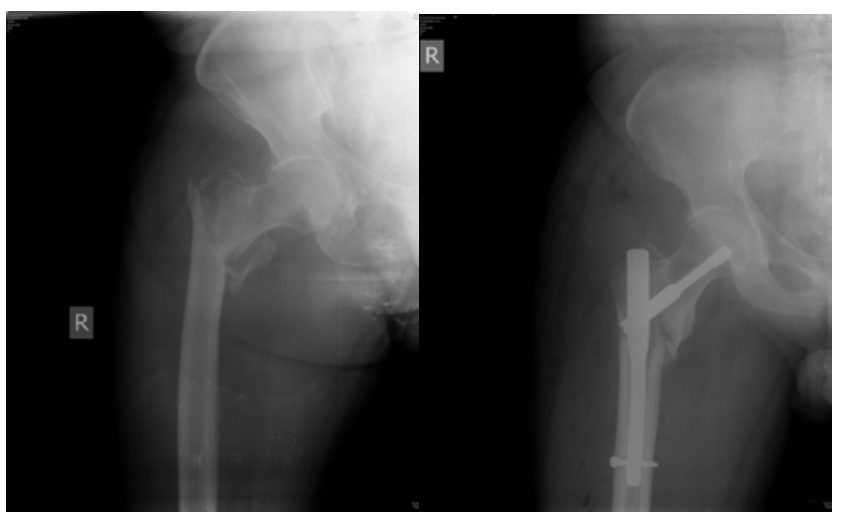

Figure 2: Type 5 trochanteric fracture according to the Jensen-Michaelsen classification (left), fixed with the Standard Bioimpianti "basic-nail" (right).

All the patients underwent the procedure at the Clinic for Orthopedics and Traumatology, Clinical Center Niš, in the period from June 2014 to November 2015.

The surgical technique was the same, minimally 
invasive, regardless of the fracture type. There was no need for the wound drainage. We used 37 standard and 9 intermediate Bioimpianti "Basic-nails", three for stable and six for unstable fractures.

All the patients were transferred postoperatively to the Intensive Care Unit (ICU).

The following parameters were prospectively analyzed:

- Operative time

- Operative complications

- Duration of intensive care and hospitalization

- Early postoperative complications

- Transfusion requirements and volume

- Postoperative activation and mobilization of patients

Student's t-test with the critical value of 0,05 was used for the statistical analysis of parametric data.

\section{RESULTS}

Table 1 shows the results of the parameters monitored in the whole series and in both studied groups. The average procedure duration was slightly but not significantly longer in Group 2 than in Group 1 ( $p=$ $0,16)$. Postoperative transfusion was not given to 9 patients, 4 in Group 1 and 5 in Group 2. The average transfusion volume in the whole series was $560 \mathrm{ml}$. There was no significant difference in the average transfusion volume in the studied groups, although the volume in Group 2 was larger $(p=33)$. The average duration of intensive care was insignificantly longer in Group $1(p=$ $0,38)$, as well as the overall hospital stay.

There were no operative or early postoperative complications.

The rehabilitation protocol of the patients included prompt activation in bed and early mobilization of patients with the aim of preventing thromboembolic and respiratory complications. In all patients, passive and active measures of thromboembolic prophylaxis were conducted from the day of the procedure. Transfer from the sitting to the upright position and mobilization up to the pain threshold started on the first postoperative day in 36 patients. In the other 9 patients, the same rehabilitation protocol was delayed by an average of 1,5 days, until stabilization of the general condition and adequate blood substitution. The average delay was similar in both groups (1.5 days in 5 patients in Group 1; 1,4 days in 4 patients in Group 2).

\section{DISCUSSION}

The average duration of operative procedure in this study is longer than those described in other similar studies $(7,9)$. The reason for this could be the fact that Bioimpianti "basic-nail" was used as a new product for the first time in our clinic during the study, so it takes time for the team to get familiar with to the slightly different instruments set.

The average transfusion volume in this study was slightly grater than that of Donegana et al. (7), primarily due to the higher criteria for adequate postoperative blood substitution in order to provide better conditions for prompt activation and mobilization of the patients.

The protocol of early rehabilitation used in our series is similar to the protocol of Donegan et al. (7), and more dynamic than the one proposed by Gadegona et al. (9), who proposed non-weight bearing ambulation start in the second week. The fracture stability in this study did not significantly affect the readiness of patients for early activation, most probably because Bioimpianti "basic-nail" is a

Table 1: Average values of analyzed parameters in the whole series and in groups

\begin{tabular}{lcccc}
\hline \hline Parameter & Whole series & Group 1 & Group 2 & $\mathrm{p}^{*}$ \\
Operation time (min) & $82.7 \pm 21.7$ & $76 \pm 18.2$ & $85.5 \pm 22.3$ & 0.16 \\
Transfusion (ml) & $560 \pm 360$ & $555.5 \pm 342.6$ & $568.8 \pm 374.8$ & 0.33 \\
ICU stay (daysi) & $3.35 \pm 1,6$ & $3.38 \pm 1.4$ & $3.23 \pm 1.2$ & 0.38 \\
Hospitalization (daysi) & $7.5 \pm 1.6$ & $7.8 \pm 1.7$ & $7.3 \pm 1.6$ & 0.13 \\
${ }^{*}$ Compares values in Group 1 and 2. & & & \\
\hline \hline
\end{tabular}


reliable implant for both stable and unstable trochanteric fractures. After using the same implant, V. Stevanović et al. published the affirmative results in the study on intracapsular and extracapsular proximal femoral fractures (10).

\section{CONCLUSION}

Trochanteric fracture fixation with Bioimpianti "Basic-nail" is a minimally invasive, safe method, giving the similar perioperative and early postoperative outcome regardless of the fracture stability. It enables fast postoperative recovery and reduction of early postoperative complications.

\section{References}

1. The Swedish National Hip Fracture Registry 2009

2. Evans EM. The treatment of trochanteric fractures of the femur. J Bone Joint Surg $\mathrm{Br}$ 1949;31:190-203.

3. Miedel R.Outcome in patients with trochanteric and subtrochanteric femoral fractures. Thesis. Karolinska Institutet, 2011: 14-18.

4. Schipper IB, Steyerberg EW, Castelein RM, et al. Treatment of unstable trochanteric fractures. Randomised comparison of the gamma nail and the proximal femoral. J Bone Joint Surg Br. 2004; 86:86-94.

5. Menezes DF, Gamulin A, Noesberger B. Is the proximal femoral nail a suitable implant for treatment of all trochanteric fractures? Clin Orthop Relat Res. 2005; 439:221-227. http://dx.doi.org/10.1097/01.blo.0000176448.00020.fa

6. Al-yassari G, Langstaff RJ, Jones JW, Al-Lami M. The AO/ASIF proximal femoral nail (PFN) for the treatment of unstable trochanteric femoral fracture. Injury. 2002; 33:395-399. http://dx.doi.org/10.1016/S0020-1383(02)00008-6

7. Donegan DJ, Voleti PB, Lee GC, Tjoumakaris FP. Short intramedullary nailing ofintertrochanteric hip fractures in thevery elderly. University of Pensilvania Orthop J. 2012; 22: 30-33

8. Jensen JS, Michaelsen M. Trochanteric femoral fractures treated with McLaughlin osteosynthesis. Acta Orthop Scand 1975; 46:795803.

http://dx.doi.org/10.3109/17453677508989266

9. Gadegone WM and Salphale YS.Short proximal femoral nail fixation for trochanteric fractures. Journal of Orthopaedic Surgery 2010; 18(1):39-44.

10. Stevanović V, Blagojević Z, Ganić Z, Diklić I, Crnobarić A, Glisić M. Intramedullary fixation and proximal femoral fractures: diversity in use through case reports. Acta Chir Iugosl. 2010;57:35-40.

http://dx.doi.org/10.2298/ACI1001035S 


\title{
Perioperativni i rani postoperativni ishod intramedularne fiksacije stabilnih i nestabilnih trohanternih preloma
}

\author{
Nina Đorđević ${ }^{1,2}$, Miloš Stanojlović1, Saša Milenković ${ }^{1,2}$, Predrag Stojiljković1, \\ Mirjana Kocić2,3, Ivan Golubović ${ }^{1}$ \\ ${ }^{1}$ Klinika za ortopediju i traumatologiju, Klinički centar Niš, Niš, Srbija \\ ${ }^{2}$ Univerzitet $u$ Nišu, Medicinski fakultet, Niš, Srbija \\ ${ }^{3}$ Klinika za fizikalnu medicinu i rehabilitaciju, Klinički centar Niš, Niš, Srbija
}

\section{SAŽETAK}

Cilj studije bio je da se ispita da li stabilnost trohanternog preloma utiče na operativne parametre plasiranja cefalomedularnog klina, kao i na rani postoperativni period.

Studija je rađena prospektivno na 46 pacijenata sa trohanternim prelomom koji su fiksiranim cefalomedularnim klinom treće generacije. Bilo je 20 pacijenata sa stabilnim (Grupa 1) i 26 sa nestabilnim (Grupa 2) trohanternim prelomima. $\mathrm{U}$ celoj seriji, kao $\mathrm{i} u$ ispitivanim grupama, analizirani su perioperativni $\mathrm{i}$ rani postoperativni parametri.

Nije bilo satističke razlike u prosečnom trajanju operacije $u$ ispitivanim grupama. Broj pacijenata koji je zahtevao transfuziju, kao i količina date krvi, bili su slični u obe grupe. Prosečno vreme boravka u Jedinici intenzivne nege (JIN) i u bolnici bilo je nešto duže u Grupi 1, ali ne i značajno. U obe grupe $80 \%$ pacijenata je započelo protokol rane rehabilitacije.

Fiksacija trohanternih preloma cefalomedularnim klinom je minimalno invazivna i sigurna metoda koja daje sličan perioperativni i rani postoperativni rezultat nevezano za stabilnost preloma. Ona obezbeđuje brzi postoperativni oporavak i omogućava ranu mobilizaciju.

Ključne reči: trohanterni prelom, stabilnost, cefalomedularni klin, operativni parametri, rana postoperativna rehabilitacija 